Терапевтична стоматологія

УДК 616.314.1:616-002.78-092(048.8)

DOI 10.11603/2311-9624.2020.1.12040

(С). І. Пупін, К. А. Мороз, О. М. Виноградова, Р. М. Гнідь, М. Р. Гнідь, Т. В. Сагайдак

Львівський національний медичний університет імені Данила Галицького

e-mail: olenka.vynogradova@gmail.com

\title{
Генералізований пародонтит і подагра: порівняння патогенетичних механізмів розвитку (огляд літератури)
}

ІНФОРМАЦІЯ

Надійшла до редакції/Received: 11.01.2021 p.

Ключові слова: генералізований пародонтит; подагра; патогенез.

\section{АНОТАЦІЯ}

Резюме. У статті представлено огляд літератури щодо сучасного бачення патофізіологічних механізмів, які формуються при подагрі та їх порівняння з такими при генералізованому пародонтиті. Подагра - хронічне прогресуюче захворювання, пов’язане з порушенням пуринового обміну, що характеризується підвищенням рівня сечової кислоти у крові (гіперурикемія) і відкладанням у тканинах опорно-рухового апарату та внутрішніх органів натрієвої солі сечової кислоти (уратів) із розвитком гострого артриту та утворенням подагричних вузликів (тофусів). Виникнення первинної подагри пов’язують зі спадково зумовленими дефектами у структурі й діяльності ферментів, які контролюють пуриновий обмін; спадковими порушеннями екскреторної функції нирок. Вторинна подагра може виникнути як один із паранеопластичних синдромів і як негативний побічний ефект хіміотерапії, при яких відбувається масивний розпад ядерних субстанцій. Факторами, які провокують загострення подагри, є дієта з високим вмістом пуринів, алкоголь, фізична активність. Характерною особливістю подагри є їі поліморбідність: кожен пацієнт має в анамнезі від 3 до 6 коморбідних захворювань, серед яких найпоширенішими і найсерйознішими $є$ хронічна серцево-судинна та хронічна ниркова недостатність. Системні порушення при подагрі, серед яких - хронічне автоімунне запалення, оксидативний стрес, ендотеліальна дисфункція і високий ризик розвитку атеросклерозу можуть створити передумови як для розвитку, так і для обтяження деструктивно-запальних уражень пародонта, що зумовлює актуальність дослідження пародонтального статусу в цих хворих і розробки для них лікувально-профілактичних комплексів.

Мета дослідження - на основі аналізу літературних даних проаналізувати та порівняти патогенетичні механізми генералізованого пародонтиту та подагри.

Висновки. Виходячи 3 даних літератури, при подагрі як метаболічному захворюванні, пов'язаному з порушенням обміну білків, формується хронічне автоімунне запалення й оксидативний стрес, що зумовлює високий ризик розвитку атеросклерозу; формуються умови, що можуть вплинути на кістковий метаболізм. Таким чином, сформовані при подагрі патогенетичні механізми створюють умови як для розвитку, так і для обтяження деструктивно-запальних уражень пародонта.
Вступ. Серед стоматологічних захворювань за частотою, інтенсивністю і руйнівними наслідками для зубощелепного апарату домінує пародонтит, етіопатогенез якого, згідно з сучасними знаннями, визначається двома типами чинників: індукуючими зовнішніми і системними. За різними даними у 85-97 \% випадків пародонтит поєднується із сома- 
тичною патологією. При коморбідному перебігу можливі взаємовплив і взаємопідсилення спільних патогенетичних механізмів, що може ускладнити перебіг обох захворювань і вплинути на ефективність лікування $[1,2]$.

Вказане ставить вивчення патогенетичних взаємозв'язків запально-дистрофічних уражень пародонта і внутрішніх органів, з розробкою на цій основі комплексних підходів до їх лікування, у ряд найбільш актуальних медико-соціальних проблем.

Серед численних повідомлень, присвячених вивченню взаємозв'язів між пародонтитом і загальносоматичними захворюваннями, не зустрічаються такі щодо впливу подагри на стан пародонта. Це стало підставою для проведення аналізу доступних літературних даних щодо патогенетичних механізмів, які формуються при подагрі та їх порівняння 3 такими при генералізованому пародонтиті.

Метою дослідження було на основі аналізу літературних даних проаналізувати та порівняти патогенетичні механізми генералізованого пародонтиту та подагри.

Матеріали і методи. У дослідженні використано бібліосемантичний та аналітичний методи. Для вирішення поставленої мети здійснено літературний огляд 51 фахового джерела, $з$ яких 26 вітчизняних та 25 зарубіжних.

Результати досліджень та їх обговорення. Подагра (МКХ-10: М10 Подагра) - хронічне прогресуюче захворювання, пов'язане з порушенням пуринового обміну, що характеризується підвищенням рівня сечової кислоти у крові (гіперурикемія) і відкладанням у тканинах опорно-рухового апарату та внутрішніх органів натрієвої солі сечової кислоти (уратів) 3 розвитком гострого артриту та утворенням подагричних вузликів (тофусів).

Поширеність подагри у світі становить від 0,3 до 1,7 \%; в Україні - 0,4 \% дорослого населення. Хворіють переважно чоловіки, пік захворювання - 35-55 років. Жінки хворіють рідше, переважно у віці 55-70 років. Подагра відноситься до давно відомих захворювань, однак причини її розвитку та патогенез не до кінця ясні. Виникнення первинної подагри пов'язують зі спадково зумовленими дефектами у структурі та діяльності ферментів, які контролюють пуриновий обмін; спадковими порушеннями екскреторної функції нирок. Вторинна подагра може виникнути як один із паранеопластичних синдромів і як негативний побічний ефект хіміотерапії, при яких від- бувається масивний розпад ядерних субстанцій. Факторами, які провокують загострення подагри, є дієта з високим вмістом пуринів, алкоголь, фізична активність [3-6].

Особливістю подагри, що спостерігається в останні десятиліття, $є$ активне зростання поширеності, особливо у молодому віці, ранне формування ускладнень, залучення у патологічний процес серцево-судинної системи і нирок. У більшості випадків причиною смерті хворих на подагру є серцево-судинні ускладнення, пов'язані з атеросклерозом.

В основі подагри лежить порушення пуринового обміну - одного з найважливіших метаболічних циклів, який пов'язаний з обміном нуклеїнових кислот у вільному стані чи в складі нуклеопротеїнів і займає ведуче місце у синтезі й розпаді білків.

Тривалий час подагру пов'язували в основному тільки 3 подагричним артритом, сьогодні гіперурикемію (підвищення рівня сечової кислоти в крові понад 0,42 мм/л у чоловіків i 0,36 мм/л у жінок) при подагрі розглядають як один із компонентів метаболічного синдрому, який виявляють у $3 / 4$ хворих [7-9].

Подагра перебігає у вигляді нападів подагричного артриту, в генезі якого лежить кристаліндукуюче запалення.

Кристали моноурату натрію, утворення яких починається при перевищенні рівня сечової кислоти в сироватці крові 0,4 ммоль/л, відкладаються в синовіальних оболонках суглобів, фагоцитуються макрофагами, що призводить до вивільнення IL1 $\beta$, інформаційної молекули імунної системи, яка є важливим фактором ініціації гострого подагричного артриту, а також регулює проліферацію клітин, диференціювання та апоптоз [10, 11]. Саме цей прозапальний цитокін може викликати вивільнення широкого спектра медіаторів запалення, зокрема фактора некрозу пухлини (TNFa), які безпосередньо відповідають за приплив нейтрофілів до синовії $[12,13]$ і розвитку хронічного аутоімунного асептичного запалення в синовіальних оболонках $[10,11]$.

Кристаліндукуюче запалення також розвивається у нирковій тканині, що може призвести до зморщування нирок із розвитком хронічної ниркової недостатності (подагричні нирки), а також в інтимі судин, що зумовлює розвиток дисфункції ендотелію $[14,15]$.

Попри відмінність причинного фактора, спільність запалення у тканинах пародонта i тканинах суглобів, нирок, ендотелію при по- 
дагрі є цілком природною, оскільки кристали моноурату натрію індукують відповідь неспецифічної ланки вродженого імунітету, подібну до мікробного процесу [11].

Основним етіологічним чинником захворювань пародонта $є$ мікробний зубний наліт, при цьому ступінь тяжкості, швидкість прогресування пародонтиту і прогноз його лікування залежать від стану захисних сил організму, які можуть як обмежувати, так i сприяти деструктивним процесам у пародонтi [16-18].

Пусковим механізмом запальної реакції при пародонтиті є ушкодження клітин і мікросудин ротової порожнини компонентами зубної бляшки, що призводить до цілого каскаду реакцій із виділенням вільнорадикальних продуктів, протеолітичних ферментів, ейкозаноїдів. Особливою, як і при подагричному запаленні, є роль цитокінів, які керують біологічною активністю у вогнищі запалення та значною мірою визначають швидкість розвитку, інтенсивність і поширеність будь-якого запального процесу [19].

Згідно із сформульованою в останні роки цитокіновою концепцією, активація пародонтопатогенними мікроорганізмами моноцитів і макрофагів на рівні зубоясенного з'єднання збільшує продукцію цими клітинами прозапальних цитокінів, які володіють властивістю стимулювати запальну реакцію. Підвищений викид цитокінів прозапальної ланки призводить до дисбалансу прозапального (IL1 $\beta$, IL6, IL8, TNFa) і протизапального цитокінового пулу (IL4, IL10). Ушкоджувальна дія прозапальних цитокінів призводить до розвитку самопідтримувального запального процесу в пародонті, що зумовлює порушення регенерації тканин пародонта, утворення пародонтальної кишені й резорбції альвеолярної кістки [20-22].

Запалення рідко розглядають як локалізований процес, оскільки можливою є системна десимінація локально утворених медіаторів запалення. Тому запальні процеси, при їх одночасному існуванні, можуть впливати один на одного. Загострення, а також збереження латентного запалення при подагрі можуть таким чином зумовити загострення і підтримувати запалення тканин пародонта, сповільнювати їх відновлення при лікуванні.

Водночас, мікрофлора пародонтальних кишень може потрапити у загальне кровоносне русло і впливати на віддалені системні орга- ни [23]. Зокрема, існують дані, що пародонтопатогени, зокрема Porfyromonas gingivalis, беруть участь у розвитку атеросклерозу, що підтверджується їх наявністю в атеросклеротичних бляшках коронарних артерій [24, 25].

В останні десятиліття активно вивчається роль гіперурикемії як незалежного чинника ризику розвитку кардіоваскулярної патології, підвищення серцево-судинної і загальної смертності. Ефект сечової кислоти у розвитку кардіоваскулярного ризику пов'язують 3 ендотеліальною дисфункцією, у виникненні якої ключову роль відводять блокуванню продукції оксиду нітрогену (NO), в результаті чого знижується його системна вазодилататорна дія. Оксид нітрогену (NO), який вивільняється ендотелієм судин у відповідь на будь-який стимул, є унікальним регулятором гомеостазу. Завдяки вазорелаксуючій дії, NO протистоїть чинникам вазоконстрикції (ендотеліну-1 i ангіотензину), забезпечуючи судинний тонус, адекватний до наявних потреб. Порушення балансу вазодилататори/вазоконстриктори лежить в основі формування ендотеліальної дисфункції [26-28].

Блокаду синтезу NO у хворих із гіперурикемією пов'язують з гіперпродукцією вільних радикалів. Сечова кислота є сильним відновлювачем (діє як антиоксидант) і забезпечує 60-70 \% усієї антиоксидантної ємності плазми крові. Однак при окисненні пуринових субстратів до сечової кислоти під дією ферменту ксантиноксидази, в інтрацелюлярному просторі утворюється велика кількість вільних радикалів кисню [29].

Якщо продукція вільних радикалів кисню знаходиться поблизу синтезованого NO, то ці два радикали реагують між собою 3 утворенням пероксинітрату ONOO-. Як наслідок оксид нітрогену інактивується, а утворений пероксинітрат ONOO-, який є дуже сильним оксидантом, поглиблює існуючий оксидативний стрес, зумовлюючи підвищене окиснення ліпопротеїнів низької щільності в стінці артерій, що призводить до розвитку раннього атеросклерозу. Така подвійна прооксидантноантиоксидантна роль сечової кислоти характеризується окремим терміном «парадокс сечової кислоти».

Ушкодження ендотелію судин кристалами сечової кислоти зумовлює активацію прозапальних цитокінів, які, будучи головними факторами формування запальної відповіді, одночасно здатні підвищувати прокоагуля- 
ційну властивість крові, впливати на метаболізм ліпідів, викликати навантаження, такими є насамперед коронарні судини [30].

Сьогодні ендотеліальну дисфункцію, яку вважають основою патогенезу атеросклерозу, розглядають не тільки як маркер кардіологічних порушень, але і як системний патологічний стан, що дає можливість екстраполювати ендотеліальні порушення на весь судинний басейн [31], у тому числі на мікроциркулярне русло зубощелепної системи [32-35].

Результати досліджень судинних змін при пародонтиті створили підгрунтя для формування започаткованої А. I. Євдокімовим [36] концепції про ініціальну, тригерну роль функціональних змін судин пародонта, які виникають під впливом медіаторів запалення і проявляються в зміні реактивності й тонусу судинної стінки, і які послідовно у динаміці захворювання змінюються органічними ураженнями атеросклеротичного характеру з повною втратою здатності до пристосувальних, компенсаторних реакцій [37].

Центральну роль впливу інфекції/запалення пародонта, як фактора ризику розвитку атеросклерозу, пояснюють положенням «активації ендотелію судин» [38] у такому представленні: циркулюючі ендотоксини бактерій зубної бляшки викликають зміни цитокінової регуляції; прозапальні цитокіни і хемокіни, утворені в надлишковій кількості змінюють регуляцію поверхневих рецепторів клітин ендотеліальної вистилки і призводять до вираженої адгезії молекул. У результаті моноцити периферійної крові затримуються і в наступному адгезуються до ендотелію судин, мігрують в субендотеліальний простір і стають тканинними макрофагами. Макрофаги захоплюють холестерин у вигляді окиснених ліпопротеїнів низької щільності, перетворюються у пінисті клітини, які підлягають апоптичному розпаду з депонуванням ліпідів у субендотеліальному просторі. Таким чином відбувається формування атеросклеротичних бляшок, які стають місцями хронічного запалення [39, 40].

Порушення мікроциркуляції призводить до різкого погіршення трофіки пародонтальних тканин: значно порушується постачання мікроелементів, амінокислот, вітамінів, кисню. За умов гіпоксії для забезпечення клітин енергією хоча б на мінімальному рівні, замість ефективного способу її отримання в результаті окисно-відновних процесів, включаються примітивні способи вироблення енергії за допомогою вільнорадикального окиснення [41].

Джерелом активних форм кисню при запаленні також є їх викид у навколишні структури активованими нейтрофілами. Гіперпродукція вільних радикалів у цьому випадку носить адаптивний характер, оскільки вони виконують захисну функцію, здійснюючи лізис потогенних мікроорганізмів [42]. Водночас, надмірна активація вільнорадикальних процесів передбачає можливість порушення редоксзалежих шляхів регуляції клітин через виснаження антиоксидантних систем. Стан дисбалансу між активними формами кисню і наявністю та активністю антиоксидантних систем визначають як оксидативний стрес, який $є$ важливим біохімічним порушенням при низці патологічних станів і захворювань [43] у тому числі і захворюваннях пародонта.

При зниженні спроможності фізіологічних антиоксидантних систем вільнорадикальне окиснення, окремим проявом якого є пероксидне окиснення ліпідів біологічних мембран, розвивається лавиноподібно, що призводить до деструкції клітинних мембран і загибелі клітин із вивільненням ендогенних токсинів. Порушується клітинний поділ і накопичуються токсичні продукти пероксидної денатурації ліпідів і білків. Активація вільнорадикального окиснення в епітеліальному шарі й глибших структурах пародонта може стати одним із факторів, які пригнічують резистентність останнього до несприятливих впливів, що створює умови до практично безперешкодного розповсюдження запального процесу на альвеолярну кістку.

Тривале накопичення сечової кислоти сприяє утворенню тофусів, які складаються з кристалів моноурату натрію у матриксі ліпідів, білків та полісахаридів. Локально у межах цих тофусів виробляються кістково-резорбтивні остеокласти, які призводять до прогресування ерозії кісток [44]. Ушкодження кістки та хрящової тканини зумовлює підвищений рівень прозапальних цитокінів, що виникає під час спалахів подагричного артриту. За даними літератури у хворих на подагру виявляють порушення метаболічних процесів кісткової тканини, що характеризується тенденцією до остеопенії, недостатньою мінералізацією кісткового матриксу з порушенням його архітектоніки [45].

Як один із ключових механізмів змін кісткової тканини при пародонтиті розглядають 
гіперекспресію прозапальних цитокінів у ясенній рідині внаслідок переключення імунної відповіді на Th1-тип реагування і зниження активності В-лімфоцитів. Значимими за ефектом дії на кісткову тканину є IL1及, IL6 i TNFa, які відіграють важливу роль у регуляції функції остеокластів [46], унаслідок чого збільшується швидкість остеокластичного розсмоктування, знижується активність остеобластів, виникає дисбаланс між резорбцією і формуванням кісткової тканини. Посилення катаболічних процесів і ослаблення біосинтезу, насамперед органічної основи тканин пародонта, призводять до руйнування усіх елементів пародонтального комплексу [47].

Альвеолярний відросток є наймолодшим кістковим утворенням в онтогенетичному розвитку людини, тому альвеолярна кістка $€$ більш уразливою до впливу зовнішніх і внутрішніх факторів [48, 49]. На формуванні органічного міжклітинного матриксу кістки остеобластами може позначитися системне порушення білкового обміну при подагрі. Вплинути на метаболізм кісткової тканини також може часте застосування хворими на подагру глюкокортикоїдів, які мають різноплановий вплив на кальцієвий метаболізм і функцію клітин кісткової тканини: гальмують синтез колагену I типу, пришвидшують розпад білків, зумовлюють посилення утворення остеокластів і резорбції кістки $[50,51]$.

Висновки. Виходячи 3 даних літератури, при подагрі, як метаболічному захворюванні, пов’язаному з порушенням обміну білків, формується хронічне автоімунне запалення і оксидативний стрес, що зумовлює високий ризик розвитку атеросклерозу; формуються умови, що можуть вплинути на кістковий метаболізм. Таким чином, сформовані при подагрі патогенетичні механізми створюють умови як для розвитку, так і для обтяження деструктивно-запальних уражень пародонта.

\section{(СТ. И. Пупин, Е. А. Мороз, Е. Н. Виноградова, Р. М. Гнидь, М. Р. Гнидь, Т. В. Сагайдак}

Львовский национальный медицинский университет имени Данила Галицкого

\section{Генерализованный пародонтит и подагра: сравнение патогенетических механизмов развития (обзор литературы)}

Резюме. В статье представлен обзор литературы о современном виденье патофизиологических механизмов, которые формируются при подагре и их сравнение с таковыми при генерализованном пародонтите. Подагра - хроническое прогрессирующее заболевание, связанное с нарушением пуринового обмена, характеризующееся повышением уровня мочевой кислоты в крови (гиперурикемия) и отложением в тканях опорно-двигательного аппарата и внутренних органов натриевой соли мочевой кислоты (уратов) с развитием острого артрита и образованием подагрических узелков (тофусов). Возникновение первичной подагры связывают с наследственно обусловленными дефектами в структуре и деятельности ферментов, контролирующих пуриновый обмен; наследственными нарушениями экскреторной функции почек. Вторичная подагра может возникнуть как один из паранеопластических синдромов и как негативный побочный эффект химиотерапии, при которых происходит массивный распад ядерных субстанций. Факторами, которые провоцируют обострение подагры, диета с высоким содержанием пуринов, алкоголь, физическая активность. Характерной особенностью подагры является ее полиморбидность: каждый пациент имеет в анамнезе от 3 до 6 коморбидных заболеваний, среди которых наиболее распространенными и серьезными является хроническая сердечно-сосудистая и хроническая почечная недостаточность. Системные нарушения при подагре, среди которых - хроническое аутоиммунное воспаление, оксидативный стресс, эндотелиальная дисфункция и высокий риск развития атеросклероза могут создать предпосылки как для развития, так и для обременения деструктивно-воспалительных поражений пародонта, что обуславливает актуальность исследования пародонтального статуса у этих больных и разработки для них лечебно-профилактических комплексов.

Цель исследования - на основе анализа литературных данных проанализировать и сравнить патогенетические механизмы генерализованного пародонтита и подагры.

Выводы. Исходя из данных литературы, при подагре как метаболическом заболевании, связанном с нарушением обмена белков, формируется хроническое аутоиммунное воспаление и оксидативный стресс, что приводит к высокому риску развития атеросклероза; формируются условия, которые могут повлиять на костный метаболизм. Таким образом, сформированы при подагре патогенетические 
механизмы создают условия как для развития, так и для отягощения деструктивно-воспалительных поражений пародонта.

Ключевые слова: генерализованный пародонтит; подагра; патогенез.

\section{(CT. I. Pupin, K. A. Moroz, O. M. Vynogradova, R. M. Gnid, M. R. Gnid, T. V. Sagaydak Danylo Halytsky Lviv National Medical University \\ Generalized periodontitis and gout: a comparison of pathogenetic mechanisms of development (literature review)}

Summary. The article presents a review of the literature on the modern vision of pathophysiological mechanisms that are formed in gout and their comparison with those of generalized periodontitis. Gout is a chronic progressive disease associated with impaired purine metabolism, characterized by increased levels of uric acid in the blood (hyperuricemia) and deposition in the tissues of the musculoskeletal system and internal organs of sodium uric acid (urate) with the development of acute arthritis and gout. nodules (tofus). The occurrence of primary gout is associated with hereditary defects in the structure and activity of enzymes that control purine metabolism; hereditary disorders of excretory renal function. Secondary gout can occur as one of the paraneoplastic syndromes and as a negative side effect of chemotherapy, in which there is a massive decay of nuclear substances. Factors that provoke exacerbation of gout are a diet high in purines, alcohol, physical activity A characteristic feature of gout is its polymorbidity: each patient has a history of 3 to 6 comorbid diseases, among which the most common and most serious are chronic cardiovascular and chronic renal failure. Systemic disorders in gout, including chronic autoimmune inflammation, oxidative stress, endothelial dysfunction and a high risk of atherosclerosis can create preconditions for both the development and aggravation of destructive inflammatory lesions of the periodontium, which determines the relevance of the study of periodontal status in these patients. for them treatment and prevention complexes.

The aim of the study - based on the analysis of literature data to analyze and compare the pathogenetic mechanisms of generalized periodontitis and gout.

Conclusions. According to the literature, gout as a metabolic disease associated with impaired protein metabolism, develops chronic autoimmune inflammation and oxidative stress, which causes a high risk of atherosclerosis; conditions are formed that can affect bone metabolism. Thus, the pathogenetic mechanisms formed in gout create conditions for both the development and aggravation of destructive-inflammatory lesions of the periodontium.

Key words: generalized periodontitis; gout; pathogenesis.

\section{СПИСОК ЛІТЕРАТУРИ}

1. Журбенко В. А. Роль соматической патологии в развитии заболеваний тканей пародонта / В. А. Журбенко // Int. J. Appl. Fund. Res. - 2016. - № 1 (Ч. 1). - C. 92. - URL: https://www.applied-research.ru/ $\mathrm{ru} /$ article/view?id=8307.

2. Periodontal health and systemic disorders / Y. T. Teng, G. W. Taylor, F. Scannapieso [et al.] // J. Can. Dent. Assoc. - 2002. - Vol. 68 (3). - P. 188-192.

3. Коваленко В. М. Національний підручник 3 ревматології / В. М. Коваленко, Н. М. Шуба. - К. : МOPIOH, 2013. -672 c.

4. Яременко О. Б. Практическая ревматология: современные аспекты / О. Б. Яременко. - К. : Здоровье Украины, 2015. - 337 с.

5. Подагра / А. Максудова, И. Салихов, Р. Хабиров, Т. Халфина. - М. : МЕДпресс-информ, 2017. - 112 с.

6. Шуба Н. М. Роль гиперурикемии в развитии кардиоваскулярной патологии / Н. М. Шуба, Т. Д. Воронова, С. В. Литвиненко // Укр. ревматол. журнал. 2017. - № 2 (68). - С. 38-46.

7. Встречаемость метаболического синдрома и его влияние на сердечно-сосудистый риск у больных подагрой / И. И. Польская, И. М. Марусенко, Т. И. Кулагина, Н. Н. Везикова // Рациональная фармакотерапия в кардиологии. - 2017. - Т. 13, № 4. - С. 476-477. 8. Serum uric acid and its association with metabolic syndrome and carotid atherosclerosis in obese children / L. Pacifico, V. Cantisani, C. Anania [et al.] // Eur. J. Endocrinol. - 2009. - Vol. 160 (1). - C. 45-52.

9. До питання оцінки серцево-судинного ризику у хворих на первинну хронічну подагру в поєднанні з метаболічним синдромом / А. О. Черняєва, М. Р. Микитюк, Ю. І. Караченцев, Н. О. Кравчун // Міжнар. ендокринол. журнал. - 2019. - Т. 15, № 4. - С. 298-303. 10. Engagement of fatty acids with Toll-like receptor 2 drives interleukin-1 beta production via the ASC/ caspase 1 pathway in monosodium urate monohydrate crystal-induced gouty arthritis / L. A. Joosten, M. G. Netea, E. Mylona [et al.] // Arth. Rheum. - 2010. Vol. 62 (11). - P. 3237-3248.

11. Gonzalez Emilio B. An update on the pathology and clinical management of gouty arthritis / B. Gonzalez 
Emilio // Clin. Rheumatol. - 2012. - Vol. 31 (1). - P. 13-21. 12. Cleophas T. O. Factors modulating the inflammatory response in acute gouty arthritis / T. O. Cleophas, M. C. Crişan, L. A. Joosten // Curr. Opin. Rheumatol. 2017. - Vol. 29 (2). - P. 163-170.

13. Transmembrane TNF-a is sufficient for articular inflammation and hypernociception in a mouse model of gout / F. A. Amaral, L. F. Bastos, T. H. C. Oleveira [et al.] // Eur. J. Immunol. - 2016. - Vol. 46 (1). - P. 204-211. 14. Борисов В. В. Нарушения пуринового обмена и их коррекция: взгляд уролога. Клиническая лекция / В. В. Борисов // Consilium Medicum. - 2017. - Т. 19, № 9. - С. 129-133.

15. Елисеев М. С. Хронические болезни почек: роль гиперурикемии и возможности уратснижающей терапии / М. С. Елисеев // Совр. ревматол. - 2018. T. 12, № 1. - C. 60-65.

16. Борисенко А. В. Зависимость между составом микрофлоры пародонтальных карманов и характером течения генерализованного пародонтита / А. В. Борисенко, Л. И. Тивоненко, Н. В. Ахрамеева // Совр. стоматология. - 2005. - № 3 (31). - С. 50-52.

17. Bacterial colonization during de novo plaque formation / P. Ramberg, S. Sekino, N. G. Uzel [et al.] / J. Clin. Periodontol. - 2003. - Vol. 30 (11). - P. 990-995.

18. Socransky S. S. Periodontal microbial ecology / S. S. Socransky, A. D. Haffajee // Periodontol 2000. - 2005. - Vol. 38. - Р. 135-187.

19. Александрова Ю. Н. О системе цитокинов / Ю. Н. Александрова // Педиатрия. - 2007. - № 3. P. 125-127.

20. Okada H. Cytokine expression in periodontal health and disease / H. Okada, S. Murakami // Crit. Rev. Oral Biol. Med. - 2007. - Vol. 9 (3). - P. 248-266.

21. Борисенко А. В. Порушення місцевого імунітету та цитокінового статусу у хворих на генералізований пародонтит / А. В. Борисенко, Ю. Г. Коленко, Т. О. Тімохіна // Сучасна стоматологія. - 2019. - № 1. - С. 34-37.

22. Мащенко И. С. Обмен цитокинов у больных с генерализованным пародонтитом / И. С. Мащенко // Совр. стомат. - 2004. - № 1. - С. 73-75.

23. Цепов Л. М. Пародонтит: локальный очаг серьезных проблем (обзор литературы) / Л. М. Цепов, Е. Л. Цепова, А. Л. Цепов // Пародонтология. 2014. - № 3. - C. 3-6.

24. Wang G. Role for Porfyromonas gingivalis in the progression of atherosclerosis / G. Wang, X. Zou, D. Huag // Med. Hypoteses. - 2009. - Vol. 72 (1). - P. 71-73. 25. Immunologic burden links periodontitis to acute coronary syndrome / J. M. Liljestrand, S. Paju, M. Pietiainen [et al.] // Atherosclerosis. - 2017. - Vol. 268. - P. 177-184.

26. Monica F. Z. The endothelium-dependent nitric oxide-cGMP pathway / F. Z. Mónica, K. Bian, F. Murad // Adv. Pharmacol. - 2016. - Vol. 77.- P. 1-27.

27. Недоспасов А. А. Биогенные оксиды азота / А. А. Недоспасов, Н. В. Беда // Природа. - 2005. № 7. - C. 35-42.

28. Endothelial function: Role, assessment and limits / C. Poissant, P. Abraham, S. Durrand [et al.] // J. Mal. Vasc. - 2014. - Vol. 39 (1). - P. 47-56.

29. Superoxide radical production by allopurinol and xantine oxidaze / C. Galbusera, P. Orth, D. Fedida, T. Spector // Biochem. Phrmacol. - 2006. - Vol. 71 (12). P. 1747-1752.
30. Vanhoutte P. M. Endotelial dysfunction: the first step toward coronary atherosclerosis / P. M. Vanhoutte // Circ. J. - 2009. - Vol. 73 (4). - P. 595-601.

31. The vascular endothelium and human diseases / P. Rajendren, T. Rengarajan, J. Thangavel [et al.] // Int. J. Biol. Sci. - 2013. - Vol. 10 (9). - P. 1057-1069.

32. Ким М. И. Воспалительные заболевания пародонта как проявление системной дисфункции эндотелия / М. И. Ким // Кримський терапевт. журнал. - 2012. - № 2. - С. 38-40.

33. Periodontal treatment improves endothelian dysfunction in patients with periodontitis / G. Seinost, G. Wimmer, M. Skerget [et al.] // Am. Heart J. - 2005. Vol. 149 (6). - P. 1050-1054.

34. Ризник Ю. Б. Дисфункция эндотелия сосудов пародонта и ее роль в развитии и прогрессировании генерализованного пародонтита / Ю. Б. Ризник // Biсник проблем біології і медицини. - 2014. - Вип. 2, т. 2 (108). - C. 115-120.

35. Mendes R. T. Endothelial dysfunction and periodontitis: The role of inflammatory serum diomarkers / R. T. Mendes, D. Fernandes // Dent. Hypotheses. - 2016. - Vol. 7 (1). - P. 4-11.

36. Евдокимов А. И. Об этиологии и патогенезе альвеолярной пиореи // Стоматология. - 1937. - № 6. C. 47-49.

37. Periodontitis is associated with the risk of subclinical atherosclerosis and peripheral arterial disease in Korean adults / Y. B. Ahn, M. S. Shin, D. H. Han [et al.] // Atherosclerosis. - 2016. - Vol. 251. - P. 311-318.

38. Kebschull M. "Gum bug, leave my heart flone!» - epidemiologic and mechanistic evidence linking periodontal infection and atherosclerosis / M. Kebschull, R. T. Demmer, P. N. Papapanou // J. Dent. Res. - 2010. Vol. 89 (9). - P. 879-902.

39. Charo I. F. Anti-inflammatrory therapeutics for the treatment of atherosclerosis / I. F. Charo, R. Taub // Nat. Rev. Drug. Discov. - 2011. - Vol. 10 (5). - P. 365-376. 40. Wang G. Role for Porfyromonas gingivalis in the progression of atherosclerosis / G. Wang, X. Zhou, D. Huag // Med. Hypoteses. - 2009. - Vol. 72 (1). - P. 63-71. 41. Основні аспекти гіпоксично-метаболічного стану тканин порожнини рота при захворюваннях пародонту / А. В. Борисенко, Т. М. Кучмеровська, I. Г. Васильєва [та ін.] // Современная стоматология. - 2017. - № 3. - С. 32-35.

42. Кулинский В. И. Биохимические аспекты воспаления / В. И. Кулинский // Биохимия. - 2007. - Т. 72 (6). - С. 733-746.

43. Окислительный стресс. Патологические состояния и заболевания / Е. Б. Меньшикова, Н. К. Зенков, В. 3. Панкин [и др.]. - Новосибирск : Сиб. ун-е изд-во, 2008. -284 c.

44. Schlesinger N. The pathogenesis of bone erosions in gouty arthritis / N. Schlesinger, R. G. Thiele // Ann. Rheum. Dis. - 2010. - Vol. 69 (11). - P. 1907-1912.

45. Михайлів Л. М. Сучасний стан проблеми ранньої діагностики та адекватного лікування подагри / Л. М. Михайлів // Проблеми остеології. - 2016. - № 2 (19). - C. 8-14.

46. Храмцова С. Н. Роль цитокинов и гормонов в формировании костной ткани / С. Н. Храмцова, Л. А. Щеплягина // Росс. педиатр. журнал. - 2005. № 5. - C. 25-29. 
47. Поворознюк В. В. Костная система и заболевания пародонта / В. В. Поворознюк, И. П. Мазур. - К. : Книга плюс, 2004. - 445 с.

48. Фастовець О. О. Системні порушення метаболізму кісткової тканини у хворих на генералізований пародонтит / О. О. Фастовець // Вісник стоматології. - 2007. - № 2. - С. 15-17.

49. Біохімія кісток та органів порожнини рота: навч. посіб. / Н. В. Фартушок, Н. Я. Думанчук, І. Ю Пиріг [та

\section{REFERENCES}

1. Zhurbenko, V.A. (2016). Rol somaticheskoy patologii $\mathrm{v}$ razvitii zabolevaniy tkaney parodonta [The role of somatic pathology in the development of periodontal tissue diseases]. Int. J. Applied Fund. Res., 1 (Part 1), 92. Retrieved from: https://www.applied-research.ru/ru/ article/view?id=8307 [in Russian].

2. Teng, Y.T., Taylor, G.W., Scannapieso, F., Kinane, D.F., Curtis, M., Beck, J.D., \& Kogon, S. (2002). Periodontal health and systemic disorders. J. Can. Dent. Assoc., 68 (3), 188-192.

3. Kovalenko, V.M., \& Shuba, N.M. (2013). Natsionalnyi pidruchnyk $z$ revmatolohii [National textbook on rheumatology]. Kyiv: MORION [in Ukrainian].

4.Yaremenko, O.B.(2015).Prakticheskayarevmatologiya: sovremennyye aspekty [Practical rheumatology: modern aspects]. Kyiv: Zdorovye Ukrainy [in Russian].

5. Maksudova, A., Salikhov, I., Khabirov, R., \& Khalfina, T. (2017). Podagra [Gout]. Moscow: MEDpress-inform [in Russian].

6. Shuba, N.M., Voronova, T.D., \& Litvinenko, S.V. (2017). Rol giperurikemii v razvitii kardiovaskulyarnoy patologii [The role of hyperuricemia in development of the cardiovascular diseases]. Ukr. revmatol. zhurnal. Ukr. J. Rheumatol., 2 (68), 38-46 [in Russian].

7. Polskaya, I.I., Marusenko, I.M., Kulagina, T.I., \& Vezikova, N.N.(2017).Vstrechayemostmetabolicheskogo sindroma i yego vliyaniye na serdechno-sosudistyy risk u bolnykh podagroy [Occurrence of the metabolic syndrome and its effect on cardiovascular risk in patients with gout]. Ratsionalnaya farmakoterapiya $v$ kardiologii - Rational Pharmacotherapy in Cardiology, 13, 4, 476-477 [in Russian].

8. Pacifico, L., Cantisani, V., Anania, C., Bonaiuto, E., Martino, F., Pascone, R., \& Chiesa, C. (2009). Serum uric acid and its association with metabolic syndrome and carotid atherosclerosis in obese children. Eur. J. Endocrinol., 160 (1), 45-52. DOI: 10.1530/EJE-08-0618.

9. Cherniaieva, A.O., Mykytiuk, M.R., Karachentsev, Yu.I., \& Kravchun, N.O. (2019). Do pytannia otsinky sertsevo-sudynnoho ryzyku u khvorykh na pervynnu khronichnu podahru $\mathrm{v}$ poiednanni $\mathrm{z}$ metabolichnym syndromom [Assessment of cardiovascular risk in patients with primary chronic gout combined with metabolic syndrome]. Mizhnar. endokrynol. zhurnal. - Int. J. Endocrinol., 15, 4, 298-303 DOI: http://dx.doi. org/10.22141/2224-0721.15.4.2019.174815 [in Ukrainian]. 10. Joosten, L.A., Netea, M.G., Mylona, E., Koenders, M.I., Subbarao Malireddi, R.K., Oosting, M., \& van der Meer, J.W.M. (2010). Engagement of fatty acids with Tolllike receptor 2 drives interleukin-1 beta production ін.]. - Львів : видавництво «Львівська політехніка», 2015. - 292 c.

50. Canalis E. Clinical review 83: Mechanismus of glucocorticoid action in bon: implications to glucocorticoid - induced osteoporosis / E. Canalis // J. Clin. Endocrin. Metab. - 1996. - Vol. 81 (10). - P. 34413447.

51. Sambrook P. N. Corticosteroid osteoporosis / P. N. Sambrook, J. Jones // Brit. J. Rheumatol. - 1995. Vol. 34 (1). - P. 8-12.

via the ASC/caspase 1 pathway in monosodium urate monohydrate crystal-induced gouty arthritis. Arth. Rheum., 62 (11), 3237-3248. DOI: 10.1002/art.27667

11. Gonzalez Emilio, B. (2012). An update on the pathology and clinical management of gouty arthritis. Clin. Rheumatol., 31 (1), 13-21. DOI: 10.1007/s10067-0111877-0

12. Cleophas, M.C., Crişan, M.C., \& Joosten, L.A. (2017). Factors modulating the inflammatory response in acute gouty arthritis. Curr. Opin. Rheumatol., 29 (2), 163-170. DOI: 10.1097/BOR.0000000000000366

13. Amaral, F.A., Bastos, L.F., Oleveira T.H.C., Dias, A.C.F., Oliveira, V.L.S., Tavares, L.D., ..., \& Teixeira, M.M. (2016). Transmembrane TNF-a is sufficient for articular inflammation and hypernociception in a mouse model of gout. Eur. J. Immunol., 46 (1), 204-211. DOI: 10.1002/ eji.201545798

14. Borisov, V.V. (2017). Narusheniya purinovogo obmena i ikh korrektsiya: vzglyad urologa. Klinicheskaya lektsiya [Violations of purine metabolism and their correction. The urologist's point of view. Clinical lecture]. Consilium Medicum, 19 (9), 129-133 DOI: 10.26442/2075-1753_19.9.129-133 [in Russian].

15. Eliseev, M.S. (2018). Khronicheskiye bolezni pochek: rol giperurikemii i vozmozhnosti uratsnizhayushchey terapii [Chronic kidney disease: the role of hyperuricemia and the possibility of urate-lowering therapy]. Sovr. revmatol. - Modern Rheumatology J., 12, 1, 60-65. DOI: https://doi.org/10.14412/1996-7012-2018-160-65 [in Russian].

16. Borisenko, A.V., Tivonenko, L.I., \& Akhrameyeva, N.V. (2005). Zavisimost mezhdu sostavom mikroflory parodontalnykh karmanov i kharakterom techeniya generalizovannogo parodontita [The relationship between the composition of the microflora of periodontal pockets and the nature of the course of generalized periodontitis]. Sovr. stomatologiya - Modern Dentistry, 3 (31), 50-52 [in Russian].

17. Ramberg, P., Sekino, S., Uzel, N.G., Socransky, S., \& Lindhe, J. (2003). Bacterial colonization during de novo plaque formation. J. Clin. Periodontol., 30 (11), 990-995. DOI: 10.1034/j.1600-051x.2003.00419.x

18. Socransky, S.S., \& Haffajee, A.D. (2005). Periodontal microbial ecology. Periodontol 2000, 38, 135-187. DOI: 10.1111/j.1600-0757.2005.00107.x

19. Aleksandrova, Yu.N. (2007). O sisteme tsitokinov [About the cytokine system]. Pediatriya - Pediatrics, 3, 125-127 [in Russian].

20. Okada, H., \& Murakami, S. (2007). Cytokine expression in periodontal health and disease. Crit. Rev. Oral Biol. 
Med., 9 (3), 248-266. DOI: 10.1177/10454411980090030101 21. Borysenko, A., Kolenko, Y., \& Timokhina, T. (2019). Porushennia mistsevoho imunitetu ta tsytokinovoho statusu u khvorykh na heneralizovanyi parodontyt [Disturbances of local immunity and cytokin status in patients with generalized parodontitis]. Sychasna stomatolohiya - Modern Dentistry, 1, 34-37. DOI: https:// doi.org/10.33295/1992-576X-2019-1-34-37 [in Ukrainian]. 22. Mashchenko, I.S. (2004). Obmen tsitokinov u bolnykh s generalizovannym parodontitom [Exchange of cytokines in patients with generalized periodontitis]. Sovr. stomatologiya - Modern Dentistry, 1, 73-75 [in Russian].

23. Tsepov, L.M., Tsepova, Ye.L., \& Tsepov, A.L. (2014). Parodontit: lokalnyy ochag seryeznykh problem (obzor literatury) [Periodontitis: a local focus of serious problems (literature review)]. Parodontologiya Periodontology, 3, 3-6 [in Russian].

24. Wang, G., Zou, X., \& Huag, D. (2009). Role for Porfyromonas gingivalis in the progression of atherosclerosis. Med. Hypoteses., 72 (1), 71-73. DOI: 10.1016/j.mehy.2008.04.030

25. Liljestrand, J.M., Paju, S., Pietiainen, M., Buhlin, K., Persson, G.R., Nieminen, M.S., \& Pussinen, P.J. (2017). Immunologic burden links periodontitis to acute coronary syndrome. Atherosclerosis, 268, 177-184. DOI: 10.1016/j.atherosclerosis.2017.12.007.

26. Monica, F.Z., Bian, K., \& Murad, F. (2016). The endothelium-dependent nitric oxide-cGMP pathway. Adv. Pharmacol., 77, 1-27. DOI: 10.1016/ bs.apha.2016.05.001

27. Nedospasov, A.A., \& Beda, N.V. (2005). Biogennyye oksidy azota [Biogenic nitrogen oxides]. Priroda Nature, 7, 35-42 [in Russian].

28. Poissant, C., Abraham, P., Durrand, S., HumeauHeurtier, A., Faure, S., Rousseau, P., \& Mahé, G. (2014). Endothelial function: Role, assessment and limits. J. Mal. Vasc., 39 (1), 47-56. DOI: 10.1016/j.jmv.2013.11.004

29. Galbusera, C., Orth, P., Fedida, D., \& Spector, T. (2006). Superoxide radical production by allopurinol and xantine oxidaze. Biochem. Phrmacol., 71 (12), 17471752. DOI: $10.1016 /$ j.bcp.2006.02.008

30. Vanhoutte, P. M. (2009). Endotelial dysfunction: the first step toward coronary atherosclerosis. Circ. J., 73 (4), 595-601. DOI: 10.1253/circj.cj-08-1169

31. Rajendren, P., Rengarajan, T., Thangavel, J., Nishigaki, Y., Sakthisekaran, D., Sethi, G., \& Nishigaki, I. (2013). The vascular endothelium and human diseases. Int. J. Biol. Sci., 10 (9), 1057-1069

32. Kim, M.I. (2012). Vospalitelnyye zabolevaniya parodonta kak proyavleniye sistemnoy disfunktsii endoteliya [Inflammatory periodontal disease as a manifestation of systemic endothelial dysfunction]. Krymskyi terapevt. zhurnal - Crimean Ther. J., 2, 38-40 [in Russian].

33. Seinost, G., Wimmer, G., Skerget, M., Thaller, E., Brodmann, M., Gasser, R., \& Pilger, E. (2005). Periodontal treatment improves endothelian dysfunction in patients with periodontitis. Am. Heart J., 149 (6), 1050-1054. DOI: 10.1016/j.ahj.2004.09.059

34. Riznyk, Yu.B. (2014). Disfunktsiya endoteliya sosudov parodonta i yeye rol v razvitii i progressirovanii generalizovannogo parodontita [Endothelial dysfunction of periodontal vasculature and its role in the development and progression of generalized periodontitis]. Visnyk problem biolohii i medytsyny Bull. Probl. Biol. Med., 2, 2 (108), 115-120 [in Russian].

35. Mendes, R.T., \& Fernandes, D. (2016). Endothelial dysfunction and periodontitis: The role of inflammatory serum diomarkers. Dent. Hypotheses, 7 (1), 4-11. DOI: 10.4103/2155-8213.177401

36. Yevdokimov, A.I. (1937). Ob etiologii i patogeneze alveolyarnoy piorei [On the etiology and pathogenesis of alveolar pyorrhea]. Stomatologiya - Dentistry, 6, 4749 [in Russian].

37. Ahn, Y.B., Shin, M.S., Han, D.H., Sukhbaatar, M., Kim, M.-S., Shin, H.-S., \& Kim, H.-D. (2016). Periodontitis is associated with the risk of subclinical atherosclerosis and peripheral arterial disease in Korean adults. Atherosclerosis, 251, 311-318. DOI: 10.1016/j. atherosclerosis.2016.07.898

38. Kebschull, M., Demmer, R.T., \& Papapanou, P.N. (2010). «Gum bug, leave my heart flone!»-epidemiologic and mechanistic evidence linking periodontal infection and atherosclerosis. J. Dent. Res., 89 (9), 879-902. DOI: 10.1177/0022034510375281

39. Charo, I.F., \& Taub, R. (2011). Anti-inflammatrory therapeutics for the treatment of atherosclerosis. Nat. Rev. Drug. Discov., 10 (5), 365-376. DOI: 10.1038/nrd3444. 40. Wang, G., Zhou, X., \& Huag, D. (2009). Role for Porfyromonas gingivalis in the progression of atherosclerosis. Med. Hypoteses, 72 (1), 63-71. DOI: 10.1016/j.mehy.2008.04.030

41. Borysenko, A.V., Kuchmerovska, T.M., Vasylyeva, I.H., Halanta, O.S., \& Volovyk, I.A. (2017). Osnovni aspekty hipoksychno-metabolichnoho stanu tkanyn porozhnyny rota pry zakhvoriuvanniakh parodontu [Basic aspects of hypoxic- metabolic state of oral cavity tissues in periodontal diseases]. Sovremennaya stomatologiya Modern Dentistry, 3, 32-35 [in Ukrainian].

42. Kulinskiy, V.I. (2007). Biokhimicheskiye aspekty vospaleniya [Biochemical aspects of inflammation]. Biokhimiya - Biochemistry, 72 (6), 733-746 [in Russian]. 43. Menshchikova, Ye.B., Zenkov, N.K., Lankin, V.Z., Bondar, I.A., \& Trufakin, V.A. (2008). Okislitelnyy stress. Patologicheskiye sostoyaniya $i$ zabolevaniya [Oxidative stress. Pathological conditions and diseases]. Novosibirsk: Siberian University Publishing House [in Russian].

44. Schlesinger, N., \& Thiele, R.G. (2010). The pathogenesis of bone erosions in gouty arthritis. Ann. Rheum. Dis., 69 (11), 1907-1912. DOI: 10.1136/ard.2010.128454

45. Mykhayliv, L.M. (2016). Suchasnyi stan problemy rannoi diahnostyky ta adekvatnoho likuvannia podahry [The current state of the problem of early diagnosis and adequate treatment of gout]. Problemy osteolohii Probl. Osteol., 2 (19), 8-14 [in Ukrainian].

46. Khramtsova, S.N., \& Shcheplyagina, L.A. (2005). Rol tsitokinov i gormonov $\mathrm{v}$ formirovanii kostnoy tkani [The role of cytokines and hormones in the formation of bone tissue]. Ross. pediatr. zhurnal - Russ. Pediatr. J., 5, 25-29 [in Russian].

47. Povoroznyuk, V.V., \& Mazur, I.P. (2004). Kostnaya sistema $i$ zabolevaniya parodonta [The skeletal system and periodontal diseases]. Kyiv : Knyha Plius [in Russian].

48. Fastovets, O.O. (2007). Systemni porushennia metabolizmu kistkovoi tkanyny $u$ khvorykh na 
heneralizovanyi parodontyt [System disorders of bone tissue metabolism in patients with generalized periodontitis]. Visnyk stomatolohii - Bull. Dent., 2, 15-17 [in Ukrainian].

49. Fartushok, N.V., Dumanchuk, N.Ya., Pyrih, I.Yu., Senkiv, N.P., \& Pyndus, T.O. (2015). Biokhimiya kistok ta orhaniv porozhnyny rota. Navch. pos. [Biochemistry of bones and organs of the oral cavity. Tutorial]. Lviv: vydavnytstvo «Lvivska politekhnika» [in Ukrainian].
50. Canalis, E. (1996). Clinical review 83: Mechanismus of glucocorticoid action in bon: implications to glucocorticoid - induced osteoporosis. J. Clin. Endocrin. Metab., 81 (10), 3441-3447. DOI: 10.1210/ jcem.81.10.8855781

51. Sambrook, P.N., \& Jones, J. (1995). Corticosteroid osteoporosis. Brit. J. Rheumatol., 34 (1), 8-12. DOI: 10.1093/rheumatology/34.1.8 